Article

\title{
The Effects of Consumers' Perceived Values on Intention to Purchase Upcycled Products
}

\author{
Somi Yu and Jieun Lee * \\ Department of Business Administration, Chung-Ang University, 84 HeukSeok-Ro, DongJak-Gu, Seoul 06974, \\ Korea; dojinlover7@cau.ac.kr \\ * Correspondence: jlee114@cau.ac.kr; Tel.: +82-10-8830-3884
}

Received: 13 December 2018; Accepted: 13 February 2019; Published: 16 February 2019

\begin{abstract}
As concerns around today's environmental problems increase, there is a growing need for consumers to accelerate their sustainable behaviors relating to product disposal such as product reuse and product life extension. The purpose of this study was to investigate consumers' value perceptions and their intentions to purchase upcycled products. This study identified the total perceived utility of upcycled products as six values that influence different levels of product attitude, which, in turn, affect purchase intention. In addition, the study examined the moderating role of purchase experience in the relationship between perceived value and product attitude. Survey data from 413 people in the United States were used to test our hypotheses. We found that three values (i.e., green, emotional, aesthetic) had a significantly positive effect on both product attitude and purchase intention. The moderating effect of purchase experience was found only on the paths between green and functional values and product attitude. The findings offer implications for academics, practitioners, and policymakers in designing strategies that encourage people to purchase upcycled products. We conclude that organizations should design strategies that maximize the emotional and aesthetic values of upcycled products using varied and engaging content, such as storytelling, based on each product's background.
\end{abstract}

Keywords: upcycled product; perceived product value; purchase experience; product attitude; purchase intention

\section{Introduction}

As serious waste disposal problems threaten mankind, there is an increasing social awareness of the need to conserve resources and reduce greenhouse gas emissions and landfills. Reflecting the social concerns of these serious environmental issues, consumers are increasingly urged to accelerate sustainable actions related to product disposal, such as product reuse and product life prolongation. Meanwhile, as part of this effort to reduce waste, a small but growing number of companies have begun trying to reduce waste by planning for a product's potential recycling or reuse at the end of its life before it is even made, and this process is known as "designing out waste" [1]. Wasting less can also improve profit and be expected to gain a positive corporate image as an ethical company. This need has created the popular trend of upcycling, which is considered a greener version of recycling [2]. Upcycling is defined as a process to "reuse discarded objects or materials in such a way as to create a product of higher quality or value than the original" [3] (p. 146). Since upcycled products are the result of converting old or discarded materials into something useful and often beautiful [4,5], recently, several emerging companies have been selling upcycled products as a means for future growth in the context of sustainable production or design [6]. The upcycling market worldwide is worth 150 million dollars, and upcycling has especially shown significant growth across the United States. For example, 
the number of products tagged with "upcycled" increased to 30,000 in 2011, an increase of $275 \%$ year over year, and as of 2013, that number stood at 263,685, an additional increase of $879 \%$ [7].

The scope of the products produced through upcycling also varies. These include rugs from fabric scraps, refashioned clothes, bags, remade furniture, soaps and fertilizers (and energy) from organic waste, artistic objects from scrap metal, and even an entire building from reused components from deconstruction, among many others [8]. With the elevation of consumer interest and demand for upcycled products [9], many companies are intensifying their focus on these products regardless of whether their business is online or offline [10].

However, despite such marketing trends in response to consumer interest, consumer perceptions or evaluations of upcycled products have been rarely studied in the consumer behavior literature $[9,10]$. Among the few, Wei and Jung's study [11] addressed the total perceived utility of sustainable fashion products, including their general product value (i.e., functional, emotional, social) and green value. They examined the impact of perceived values and the role of psychological factors (e.g., face-saving) on consumer intention to purchase sustainable fashion products. Considering that upcycling is a way of giving a product a whole new life by adding unique ideas and designs to discarded material beyond simple recycling [5], upcycled products are expected to deliver more product value compared to general environmental products. Therefore, the main aim of this study was to examine in-depth the role of consumption values in upcycled products. Our research model could provide a theoretical basis based on Fishbein's multiattribute model, more specifically the attitude-toward-object model. According to this model, the attitude of a consumer to a product is assumed to be determined by some salient beliefs perceived by the consumer about various pieces of information about the object (product, ideas), and by the importance evaluation of the product attribute. Consumers have a belief in the product feature after undergoing a cognitive process and form a positive or negative attitude through such a formed belief [12]. Therefore, we investigated the impact of product values on consumer attitudes and upcycled product purchase intention based on this theory.

According to the stream of research on green marketing, individual characteristics, such as demographics, lifestyle, values, knowledge, and perceived behavioral and situational factors, might explain the intention-purchase gap [13]. Although consumers struggle to infer information about the characteristics of the product they first encounter, consumers who have gained real knowledge through product experience can deduce more information on the quality or price of the product based on stored memory, which makes an attitude toward the product more positive than the consumer who lacks knowledge [14]. That is, a consumer's purchase experience might affect value perceptions of upcycled products differently based on differences in prior knowledge and product familiarity [15], but little focus has been given to comparisons of value perceptions or attitudes between first-time buyers (i.e., non-purchasers) and repetitive buyers (i.e., purchasers). Thus, this study examined the moderating role of the actual purchase experience among consumers' various personal characteristics and compared the differentiating effects on perceived product characteristics and attitudes toward upcycled products between green and non-green buyers. To design effective marketing strategies, it is important to identify the differing consumption values and product attitudes that are likely to influence purchase intent or repurchase intent by comparing consumers with experience in upcycled products to those without. Further, the consumption value differs depending on individual characteristics and product type [16]: Thus, analyzing the consumption values of upcycled products can be beneficial in terms of identifying new factors that can increase purchasing behavior. Finally, by identifying the key influential consumption values for upcycled products, the study's findings will prove useful for businesses, governments, and communities looking to increase first-time upcycled product buyers as well as repeat customers. 


\section{Materials and Methods}

\subsection{Theoretical Framework and Hypotheses}

\subsubsection{Upcycled Products and Consumers' Perceived Value}

As sustainable consumption aimed at saving the environment is now recognized as part of corporate social responsibility [17], many companies are paying more attention to the upcycle business as a green marketing strategy [18]. According to several studies [10,19], upcycling is defined and distinguished from other forms of material reuse such as downcycling and recycling. Braungart and McDonough, who were among the first to research the concept of upcycling [20], have advocated that upcycling is radical innovation for perpetually circular material reutilization, in contrast to recycling practice, which is considered downcycling [21]. Upcycling is total energy saving, whereas recycling typically breaks down the original material and makes it into something else using more energy [22]. That is, upcycling is greener and more beneficial [10]. Furthermore, upcycling is a combination of upgrading and recycling [23], a process where used materials are converted into something of higher value and/or quality in their second life, while recycling is simply used in the original form or downgraded $[20,21]$. For this reason, many business practitioners consider and sell upcycled products by transforming and creating old material into objects with new uses. Indeed, upcycling business has been actively promoted and practiced by a number of companies, including Adidas, FREITAG, and Patagonia, as well as many social enterprises and startups [10]. Adidas, one of the world's largest apparel retailers, has also produced and launched a running shoe prototype created in part from reclaimed fishing nets [10]. Although upcycled products appear in nearly every product category and are for sale throughout the market, there are few studies that have investigated consumer intention to purchase upcycled products. Prior studies $[10,11]$ have also pointed to the dearth of such studies in the marketing literature, especially in terms of consumer consumption in this context. Therefore, we focused on understanding consumers' consumption values when purchasing upcycled products.

Zeithaml [24] developed a fundamental base for the conceptualization of perceived value of a service. The majority of past research has cited the definition of perceived value that was developed by her, which is "the consumer's overall assessment of the utility of a product based on perceptions of what is received and what is given" (p. 14). While these definitions are associated with a unidimensional approach to perceived values, later studies have adopted a multidimensional approach (e.g., References [16,25]). According to the multidimensional approach, perceived value represents the sum of the different dimensions of value, which have different effects in different situations. Holbrook [26] has also suggested that a customer's perceived value can be a relativistic preference and experience depending on the individual, situation, or product. We tried to shed light on various dimensions of values related to social and psychological benefits as well as utilitarian benefits, focusing on upcycled products. Specifically, built on the consumption theory, Sweeney and Soutar [25] have found that functional, emotional, and social values are three fundamental dimensions of perceived value. Keller [27] has also suggested that functional, emotional, and social values are three fundamental dimensions of perceived value of products or service value. Wei and Jung [11] have examined the influence of perceived value on the customer's behavioral intention toward sustainable fashion products and employed functional, emotional, and social values based on Sweeney and Soutar's three fundamental dimensions of perceived theory. They also combined this with green value theory borrowed from Chen and Chang [17]. Consistent with previous studies, we employed green, functional, emotional, and social values as four reflective various dimensions of values that consumers can perceive from using a product. We noticed that such values are important factors in understanding consumer intention to purchase sustainable products. However, for upcycled products that become value-added products through the addition of ideas and designs rather than simply recycled things, other value dimensions are also influential. Therefore, this study examined value theories suggested by Wei and Jung [11] as well as other value dimensions of consumption theory focusing on upcycled product 
values. First, upcycling is seen as a promising means to reduce material and energy use and to engender sustainable production and consumption [21]. Thus, it is recognized as a greener version of recycling, requiring less energy to protect resource savings and the environment [10]. Researchers (e.g., References $[11,17])$ define green value as "a consumer's overall appraisal of the net benefit of a product or service between what is received and what is given based on the consumer's environmental desires, sustainable expectations, and green needs." From this point of view, upcycled products, which repurpose an item by requiring less energy and fewer resources rather than by adding it to the waste stream, can be considered greener products. Therefore, consumers ascribe value to the green properties of an upcycled product and have positive attitudes toward that product.

Hypothesis 1 (H1): Green value is positively associated with upcycled product attitude.

Second, an upcycled product can be functional. The design of the product encompasses a number of different practical considerations such as effectiveness, ease of use, reliability, sturdiness, durability, safety, need for maintenance, and multifunctionality [28]. Further, it helps meet the practical or utilitarian needs of the customer. In terms of upcycled product design, the focus is on minimization of any harm affecting the environment [3]. Therefore, upcycled products could be practical in a more secure way. Compared to general products, upcycled products are also cost-effective [10], as well as durable, because they use proven material despite being constructed from abandoned items through a number of cycles [29]. In other words, the consumer might perceive the functionality of the upcycled product and prefer that.

Hypothesis 2 (H2): Functional value is positively associated with upcycled product attitude.

Third, upcycling practices are activities that create better quality from waste $[27,28]$. Specifically, the recreation of materials not only adds new functions, but also serves as a unique concept interior, transforming the space in which the product is placed into something more interesting and appealing. In addition, upcycling can be used as a unique selling point because it provides an inimitable backstory [30]. As a result, consumers might perceive a special sense of joy and excitement from the upcycled product, which is important to them, as the product is unique and one of a kind. Simultaneously, customers have positive attitudes toward products when they perceive emotional value.

Hypothesis 3 (H3): Emotional value is positively associated with upcycled product attitude.

Fourth, for some consumers, upcycled products have a benefit in terms of their aesthetic appearance [10]. Upcycled products are very different from recycled products that are low-growth orientated and lack aesthetics, only emphasizing ethical responsibility awareness aimed at conserving the environment and saving resources [31]. That is, upcycled products are reincarnated into high-value-added products, applying aesthetic creativity to recycled products. Interestingly, the purchase motives behind vintage or retro products and upcycled products are similar to an aesthetics shift [10,32]. Indeed, upcycled furniture, such as a sofa that has been reupholstered using tires, wood crate nightstands, and antique typewriter keyboards, has a similar vintage appeal. In sum, customers might perceive aesthetic value from the design of upcycled products and show a positive attitude toward them.

Hypothesis 4 (H4): Aesthetic value is positively associated with upcycled product attitude.

Last, upcycled products can be an effective means of communication as social or self-expression, as they provide opportunities for visibility in situations regardless of pre- or post-product use. While the social value provided by sustainable products has been supported empirically in the literature [14], 
this study extends the previous study that consumers often express their personality through general products [33] by suggesting that upcycled products can also become a vehicle for self-expression and self-identity. Social value captures the ability to help consumers increase their perceived status in the community and/or improve their self-esteem [28]. Specifically, for upcycled products, consumers can achieve social value through the product's design, which is well recognized as eco-labeled or recycled materials. Therefore, consumers gain a sense of status and self-esteem through their perceptions of the image they evoke from the product purchase. This social self-image can be important, but actual self-image is also valuable in the upcycled product context. Consumers strive to retain their actual self-image by purchasing products that convey their self-identity and personality [34]. In particular, the use of upcycling products can instill personal meaning and character into a space by giving it more personality [5]. Sung et al. [35] (p. 2) have stated that "upcycling, as a creative, engaging user activity, may offer the experiences of self-expression, group affiliation, special memories and pleasure, all of which are possible product attachment determinants." Consumers create a strong product attachment when they recognize that a product reflects their personal image or personality [36]. Thus, consumers have positive attitudes toward upcycled products after perceiving their self-expression value. In sum, we proposed the following hypotheses.

Hypothesis 5 (H5): Social value is positively associated with upcycled product attitude.

Hypothesis 6 (H6): Self-expression value is positively associated with upcycled product attitude.

\subsubsection{Upcycled Product Attitude and Purchase Intention}

According to prior studies on attitude, attitudes cannot be perfectly predictive of behavior, because they can be strengthened or weakened by strong social pressures [37]. Particularly in products with ethical or environmental features, there is an ethical purchasing gap that describes an inconsistency between what consumers express, represented in attitudes and intentions, and their behavior [38]. However, scholars investigating green product fields still use the product attitude approach in their attempt to identify purchasing behavior for eco-friendly products $[39,40]$. Attitudes can be predictors of behavior, because when an individual forms a positive or negative attitude to certain objects, the likelihood of acting depends on that attitude. In addition, when consumers develop a positive attitude about a product, this attitude has a positive effect on future purchase intention and actual purchasing behavior [41]. Therefore, we expected that consumer attitude toward upcycled products positively influences purchase intention. According to Engel and Blackewell [42], purchase intention is an important predictor of consumption behavior, which is often used instead of actual behavior. Last, the value-attitude-behavior hierarchy model used by Homer and Kahle [43] suggests that the direct effect of value on behavior is weak and that attitude mediates these relationships. That is, attitude formation can be an essential step before purchase intention. In conclusion, we proposed the following hypotheses.

Hypothesis 7 (H7): Upcycled product attitude increases intention to purchase upcycled products.

Hypothesis 8 (H8): Upcycled product attitude mediates the relationship between perceived values and purchase intention.

\subsubsection{Purchase Experience as a Moderating Variable}

Norman and Smith [44] have suggested that past experiences can be predictors of future attitudes and buying behavior. In particular, past experience should not be ignored because ethical behavior, such as giving to charity or recycling garbage, is a habitual behavior that stems from learning [45,46]. According to prior studies $[47,48]$, knowledge of a specific product is obtained based on prior 
experience with that product, and the level of knowledge associated with this product increases interest in or preference for the product.

Purchasers and non-purchasers may have different product knowledge or familiarity due to their individual product experience: Thus, this will have a different impact on the consumer's valuation of the product. From the perspective of traditional consumer decision-making research [49-51], purchasers have more information sources that they can use to easily judge product attributes and form a well-defined system of criteria and methods for evaluating alternatives. In addition, product-related experiences generate a memory for the individual, and the product and those memories are easily accessible based on their vividness [52]. Consumers who have no prior experience, however, have a limited amount of information available when evaluating product attributes and alternatives. In this light, we can assume that there are differences between purchasers and non-purchasers in terms of how they understand new information, how they use information sources, and how easy it is for them to evaluate the product. In particular, the group familiar with the product has greater confidence when choosing and processing product attributes to make an appropriate decision [53], which, in turn, generates differences in motivational involvement with the task between the groups. In other words, we believe that the consumer's memory, knowledge, and involvement are formed by experience, and such individual differences (i.e., purchase experience versus no purchase experience) could yield differential effects on the upcycled product evaluation.

Ahn and Jung [54] have compared the purchasing behavior for environmental products among purchasers and non-purchasers. They found that purchasers largely consider the product in terms of eco-friendliness, thereby recognizing eco-labeled products, whereas non-purchasers pay greater attention to price or quality. As mentioned, studies $[10,55]$ have verified the green nature of upcycling on the grounds that products made through upcycling typically require little energy input, consume less, and divert more waste away from landfills. Thus, purchasers may see more green value in upcycled products than non-purchasers, and, in conjunction, have a positive attitude toward them.

Since purchasers have previous purchase experience and knowledge of the brands they own, those very familiar with these products have greater confidence in their attributes, such as brand name, price, and so forth [51]. Therefore, the purchaser is not expected to find it difficult or ambiguous to base decisions on functional attributes. Conversely, non-purchasers do not feel as confident evaluating the functional attributes of unfamiliar products and are more careful in choosing products with perceived greater risk. That is, upcycled products might not be accepted by non-purchasers because they could be perceived as having a higher level of performance risk over long-term use. This interpretation suggests that consumers with previous purchasing experience perceive less risk in their product evaluation because they have sufficient knowledge based on their experience with upcycled products. Therefore, we can expect that the group with product experience has a more favorable attitude in terms of the functional value of upcycled products than the group having no purchasing experience.

In parallel, emotional benefits capture the intangible and intrinsic attributes of a product in relation to a particular buying and usage situation [56]. Intangible elements linked to consumer perceived emotional value [57] can be more risky for non-purchasers who have little product knowledge due to uncertainty. Non-purchasers have relatively little intrinsic product information in their memories and a less-developed informational schema [15]: Thus, attaching emotional value to upcycled products is more difficult. However, among purchasers, as they have become more familiar with a product over a long interaction period, the emotional benefit, which is the intrinsic attribute of the upcycled product, can be evaluated more readily based on stored memories. Therefore, purchasers more readily perceive emotional value and form positive attitudes toward upcycled products relative to non-purchasers.

Clarkson et al. [58] have suggested that consumer consumption knowledge leads to greater appreciation. For instance, the ability to classify and describe art increases through experience and knowledge, which, in turn, allows the individual to appreciate the art (e.g., organization, style, content) and increases its overall aesthetic appeal [59]. In effect, consumption knowledge allows a consumer to derive more meaning from a specific consumption experience, which, in turn, increases appreciation 
of the product [60]. From this perspective, purchasers with product knowledge can better assess the aesthetic aspects of upcycle products, which, in turn, allows them to form a more positive attitude toward these products than non-purchasers with little knowledge of the products.

Several studies (e.g., References [61-63]) have explained that consumers' pre-purchase values and post-purchase values are different. First-time buyers assess the value of a product based on individual expectations [63]. Accordingly, they anticipate the symbolic value of the product, such as the social or self-expression benefits: However, they find this more difficult to gauge than buyers who have already experienced the product. Repeat buying is associated with post-purchase value, which involves value realized through product use. Boztepe [64] has suggested that post-purchase value is closely tied to the realities of the user's context. In this sense, the social benefit or self-expression benefit, which is a symbolic value, is more likely to be felt during product usage, and the buyers who learn through experience are expected to form a more positive attitude toward these aspects of upcycled products.

Hypothesis 9 (H9): Purchase experience has moderating effects between the perceived value of the upcycled product and purchase intention.

The conceptual model of this study is presented in the Figure 1.

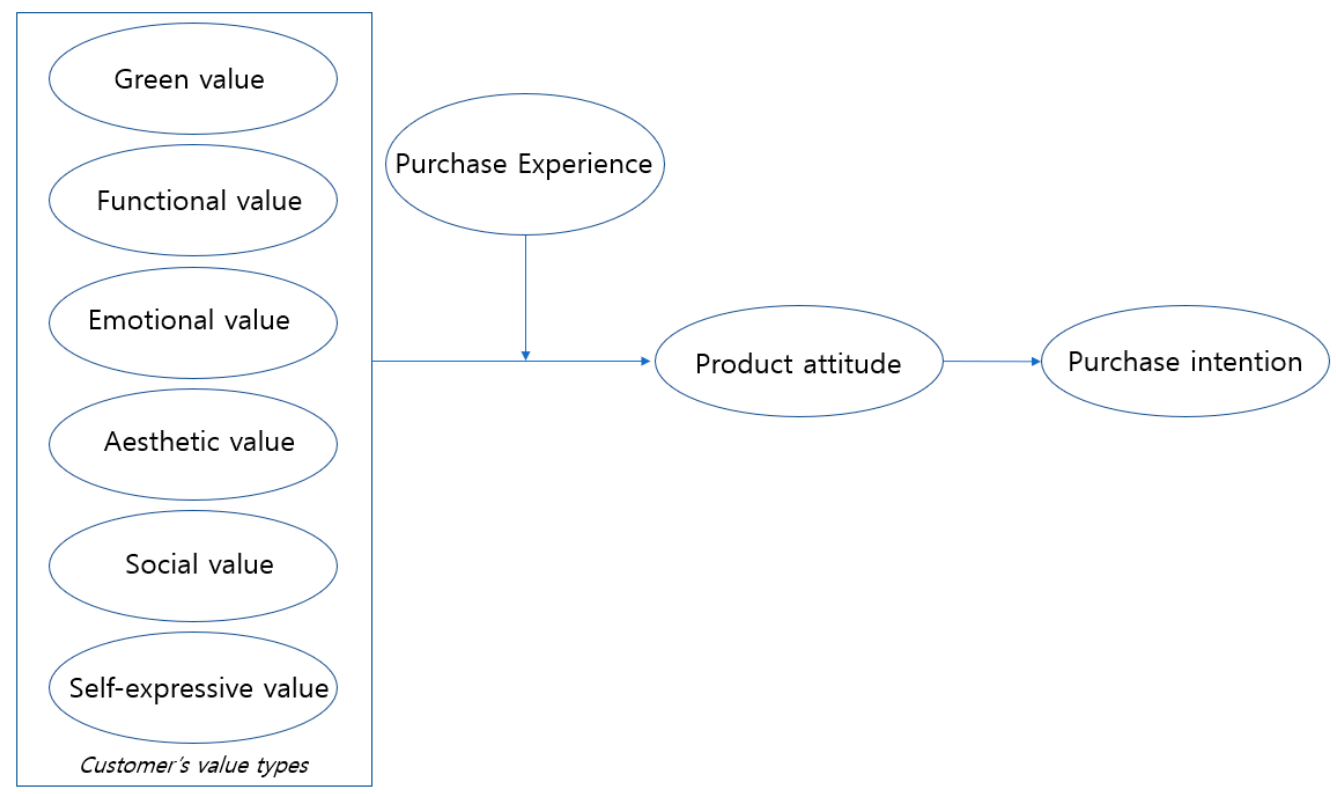

Figure 1. Conceptual model.

\subsection{Methodology}

\subsubsection{Data Collection and Sample}

An online survey was conducted using the Google Forms tool to collect data for the empirical analysis. The survey was conducted in April 2018. A total of 413 individuals residing in the United States were recruited via Amazon Mechanical Turk (M Turk), a crowdsourcing marketplace. In recent years, M Turk has emerged as a practical way for recruiting a large number of respondents for online experiments from a reasonably wide cross-section of the general public, considerably more diverse than the traditional recruitment pool of university undergraduates [65]. We analyzed data from 401 respondents who completed the entire survey. In this study, males comprised $53.6 \%$ of the respondents, while $42 \%$ were between 30 and 39 years, followed by $23.8 \%$ between 20 and 29 years, $16.3 \%$ between 40 and 49 years, $14.8 \%$ between 50 and 59 years, and $3.3 \%$ over 60 . In addition, their occupations included office workers (28.4\%), salespeople (16.5\%), engineers $(18.2 \%)$, professionals $(18.2 \%)$, the self-employed $(8.0 \%)$, and students $(2.5 \%)$. Finally, we asked respondents to indicate 
their upcycle buying experience and buying period. In response, 211 replied that they had purchased upcycled products. Most of these had purchased within one year, and the products they bought were furniture (27.2\%), a bag/purse (25.3\%), accessories (17.1\%), home decoration (14\%), office supplies $(8.9 \%)$, and clothing $(7.4 \%)$, among others.

\subsubsection{Measures}

At the beginning of the survey, we provided a brief message about the operationalized definition of upcycled products (i.e., products that are made useful by creating new ideas from resources that are used up and discarded, which is different from recycled products that simply reuse garbage), with eight exemplary images to help subjects understand the concept (see Appendix A). The remainder of the survey contained several items intended to measure perceived product value, product attitude, purchase intention, and individual characteristics (demographics). All measurement items shown in Table 1 were adapted from related prior studies. All items were measured on a seven-point Likert-type scale, ranging from "strongly disagree" (1) to "strongly agree" (7). For the moderating variable, buying experience was included as 1 if respondents had made at least one purchase and 2 if the respondent was a non-purchaser.

Table 1. Study measures.

\begin{tabular}{|c|c|c|c|}
\hline Measure & Definition & Measurement & Sources \\
\hline Green value & $\begin{array}{l}\text { The degree of customer } \\
\text { perception of environmental } \\
\text { needs, sustainable expectations, } \\
\text { and green impact from upcycled } \\
\text { products }\end{array}$ & $\begin{array}{l}\text { - This product has more environmental benefits } \\
\text { than other products. } \\
\text { - This product is environmentally friendly. } \\
\text { - This product has more environmental concern } \\
\text { than other products. } \\
\text { - This product's environmental functions } \\
\text { provide a very good value. }\end{array}$ & {$[11,17]$} \\
\hline $\begin{array}{l}\text { Functional } \\
\text { value }\end{array}$ & $\begin{array}{l}\text { The degree of customer } \\
\text { perception of the functional, } \\
\text { utilitarian, and physical } \\
\text { performance of upcycled products }\end{array}$ & $\begin{array}{l}\text { - } \quad \text { This product has consistent quality. } \\
\text { - } \quad \text { This product has an acceptable standard } \\
\text { of quality. } \\
\text { - } \quad \text { This product would perform consistently. }\end{array}$ & {$[11,25]$} \\
\hline $\begin{array}{l}\text { Emotional } \\
\text { value }\end{array}$ & $\begin{array}{l}\text { The degree of customer } \\
\text { perception of the capacity to } \\
\text { arouse feelings or affective states } \\
\text { of upcycled products }\end{array}$ & $\begin{array}{l}\text { - } \quad \text { This product is one that I would enjoy. } \\
\text { - } \quad \text { This product would make me want to use it. } \\
\text { - } \quad \text { This product is one that I would feel relaxed } \\
\text { about using. } \\
\text { - } \quad \text { This product would make me feel good. } \\
\text { - This product would give me pleasure }\end{array}$ & {$[11,25]$} \\
\hline Aesthetic value & $\begin{array}{l}\text { The degree of customer } \\
\text { perception of the attractiveness } \\
\text { and beauty of upcycled products }\end{array}$ & $\begin{array}{l}\text { - The curves and lines of this design make it } \\
\text { appealing to me. } \\
\text { - } \quad \text { I like the aesthetics of this product. } \\
\text { - } \quad \text { The design of this product is attractive. }\end{array}$ & [28] \\
\hline Social value & $\begin{array}{l}\text { The degree of customer } \\
\text { perception of the ability to } \\
\text { increase perceived status or } \\
\text { self-esteem of upcycled products }\end{array}$ & $\begin{array}{l}\text { - This product would help me feel accepted. } \\
\text { - This product would improve the way I } \\
\text { am perceived. } \\
\text { - This product would make a good impression } \\
\text { on other people. } \\
\text { - This product would give its owner } \\
\text { social approval. }\end{array}$ & {$[11,25]$} \\
\hline
\end{tabular}


Table 1. Cont.

\begin{tabular}{|c|c|c|c|}
\hline Measure & Definition & Measurement & Sources \\
\hline $\begin{array}{l}\text { Self-expression } \\
\text { value }\end{array}$ & $\begin{array}{l}\text { The degree of customer } \\
\text { perception of reflective } \\
\text { self-identity and personality from } \\
\text { upcycled products }\end{array}$ & $\begin{array}{l}\text { - This product has a strong personal meaning } \\
\text { to me. } \\
\text { - } \quad \text { This product helps me express myself. } \\
\text { - A main benefit of this product is the ability for } \\
\text { customers to express their own beliefs, values, } \\
\text { or personalities. }\end{array}$ & [66] \\
\hline $\begin{array}{l}\text { Product } \\
\text { attitude }\end{array}$ & $\begin{array}{l}\text { The degree of consumer thought } \\
\text { and beliefs around upcycled } \\
\text { products }\end{array}$ & $\begin{array}{ll}\text { - } & \text { I like upcycled products. } \\
\text { - } & \text { I have a positive emotion regarding } \\
\text { upcycled products. } \\
\text { - } \quad \text { I am satisfied with upcycled products. }\end{array}$ & [67] \\
\hline $\begin{array}{l}\text { Purchase } \\
\text { intention }\end{array}$ & $\begin{array}{l}\text { The degree of willingness to } \\
\text { purchase upcycled products }\end{array}$ & $\begin{array}{l}\text { - } \quad \text { I might purchase upcycled products. } \\
\text { - } \quad \text { I will purchase upcycled products. } \\
\text { - } \quad \text { I am willing to recommend upcycled products } \\
\text { to others. }\end{array}$ & [68] \\
\hline
\end{tabular}

\subsubsection{Method}

We ran a covariance-based analysis, structural equation modeling, using AMOS software, which allows cause-effect relationship models with latent variables using maximum likelihood estimation [69]. To estimate the moderating role, purchase experience was regarded as a nonmetric moderator, and thus we used multigroup analysis. We divided the purchase experience into a purchaser group and a non-purchaser group and analyzed the path model of each group. A confidence limit estimation has been advocated for several reasons, including that it forces researchers to consider the size of an effect in addition to making a binary decision regarding significance and that the width of the interval provides a clearer understanding of variability in the size of the effects. Thus, we tested the mediation effect of product attitude in the relationship between each product value and purchase intention using the bootstrap sampling method (bootstrap sample size $=5,000$ ) $[70]$ to generate asymmetric confidence intervals (CIs) for indirect relationships.

\section{Results}

\subsection{Measurement Model}

We conducted confirmatory factor analysis (CFA) using AMOS 21.0 to test the measurement model. The model was found to provide a good fit with the data $\left(\chi^{2} / \mathrm{df}=2.793, \mathrm{CFI}=0.942, \mathrm{TLI}=0.932, \mathrm{RMSEA}\right.$ $=0.067, \mathrm{SRMR}=0.046$ ). The overall fit met the conventional cutoff criteria [71]. In addition, CFA can be used to measure the reliability, convergent validity, and discriminant validity of the measurement model. As shown in Table 2, the squared multiple correlations (SMCs) of the measured variables were larger than 0.50, excluding GV2, which was slightly smaller than this criterion, and Cronbach's alphas for the constructs all reached a level of significance. Therefore, the constructs in this study represented acceptable reliability. Moreover, all the latent variables had a composite reliability (CR) above 0.60 and an average variance extracted (AVE) above 0.50, indicating that both CR and AVE values exceeded the corresponding cutoff criteria [72,73]. Finally, each latent variable's AVE was larger than the squared correlation between each pair of latent variables in every case, demonstrating that the constructs were distinct and adequately explained by their measurement scales (see Table 3). Hence, convergent and discriminant validity were proven to be adequate for our measurement model [74]. 
Table 2. Construct statistics.

\begin{tabular}{|c|c|c|c|c|}
\hline Construct & $\begin{array}{l}\text { Factor } \\
\text { Loadings }\end{array}$ & Cronbach's $\alpha$ & $\begin{array}{c}\text { Composite } \\
\text { Reliability (CR) }\end{array}$ & $\begin{array}{l}\text { Average Variance } \\
\text { Extracted (AVE) }\end{array}$ \\
\hline Green value & & 0.758 & 0.78 & 0.544 \\
\hline GV1 & 0.841 & & & \\
\hline GV2 & 0.432 & & & \\
\hline GV3 & 0.703 & & & \\
\hline GV4 & 0.656 & & & \\
\hline Functional value & & 0.893 & 0.897 & 0.744 \\
\hline FV1 & 0.811 & & & \\
\hline FV2 & 0.891 & & & \\
\hline FV3 & 0.884 & & & \\
\hline Emotional value & & 0.938 & 0.938 & 0.752 \\
\hline EV1 & 0.908 & & & \\
\hline EV2 & 0.908 & & & \\
\hline EV3 & 0.807 & & & \\
\hline EV4 & 0.884 & & & \\
\hline EV5 & 0.825 & & & \\
\hline Aesthetic value & & 0.828 & 0.838 & 0.634 \\
\hline AV1 & 0.751 & & & \\
\hline AV2 & 0.866 & & & \\
\hline AV3 & 0.766 & & & \\
\hline Social value & & 0.912 & 0.915 & 0.731 \\
\hline SV1 & 0.854 & & & \\
\hline SV2 & 0.92 & & & \\
\hline SV3 & 0.906 & & & \\
\hline SV4 & 0.725 & & & \\
\hline Self-expression value & & 0.822 & 0.833 & 0.629 \\
\hline SEV1 & 0.83 & & & \\
\hline SEV2 & 0.899 & & & \\
\hline SEV3 & 0.625 & & & \\
\hline Product attitude & & 0.911 & 0.911 & 0.773 \\
\hline PA1 & 0.871 & & & \\
\hline PA2 & 0.878 & & & \\
\hline PA3 & 0.889 & & & \\
\hline Purchase intention & & 0.908 & 0.907 & 0.765 \\
\hline PI1 & 0.839 & & & \\
\hline PI2 & 0.881 & & & \\
\hline PI3 & 0.902 & & & \\
\hline
\end{tabular}

Table 3. Correlations between constructs.

\begin{tabular}{llcccccccccc}
\hline & & Mean & S.D. & $\mathbf{1}$ & $\mathbf{2}$ & $\mathbf{3}$ & $\mathbf{4}$ & $\mathbf{5}$ & $\mathbf{6}$ & $\mathbf{7}$ & $\mathbf{8}$ \\
\hline 1 & GV & 5.71 & 0.99 & $\mathbf{0 . 7 3 8}$ & & & & & & & \\
2 & FV & 5.34 & 1.27 & 0.468 & $\mathbf{0 . 8 6 3}$ & & & & & \\
3 & EV & 5.50 & 1.29 & 0.578 & 0.773 & $\mathbf{0 . 8 6 7 *}$ & & & & \\
4. & AV & 5.28 & 1.73 & 0.528 & 0.778 & 0.655 & $\mathbf{0 . 7 9 6 *}$ & & & \\
5 & SV & 4.01 & 1.25 & 0.306 & 0.466 & 0.463 & 0.480 & $\mathbf{0 . 8 5 5 *}$ & & & \\
6 & SEV & 5.06 & 1.39 & 0.502 & 0.661 & 0.785 & 0.558 & 0.729 & $\mathbf{0 . 7 9 3} *$ & & \\
7 & PA & 5.47 & 1.29 & 0.549 & 0.661 & 0.798 & 0.387 & 0.733 & 0.680 & $\mathbf{0 . 8 7 9} *$ & \\
8 & PI & 5.54 & 1.40 & 0.496 & 0.657 & 0.760 & 0.374 & 0.725 & 0.658 & 0.790 & $\mathbf{0 . 8 7 5 *}$ \\
\hline
\end{tabular}

Note: GV: Green value; FV: Functional value; EV: Emotional value; AV: Aesthetic value; SEV: Self-expression value; PA: Product attitude; PI: Purchase intention. * The numbers in the diagonal row (in bold) are square roots of the average variance extracted.

As the data used in this study were collected via self-reporting, there was the potential for common method bias. To examine this possible effect for all data, we performed Harman's single-factor test [75]. After all the variables in our model were entered into an unrotated exploratory factor 
analysis, the results indicated that the most covariance explained by one factor was $42.22 \%$, below the $50 \%$ threshold. The Kaiser-Meyer-Olkin (KMO) value was 0.953 (target $>0.5)$, and the significance value of Bartlett's test of sphericity was 0.00 (target $<0.05$ ). We also ran a common latent factor test to measure the method variance in the dataset. All the delta values were less than 0.2 , which indicated that common method bias was not a major concern in the data [76]. Further, we conducted a multicollinearity test. The literature related to statistics indicates that we can use the variation inflation factor (VIF) to assess whether there is an overlap between two variables (if VIF exceeds 10, then the items in the two variables overlap). Accordingly, we conducted a VIF analysis, and the resulting values were between 1.528 (the minimum) and 4.687 (the maximum), less than the threshold, indicating that multicollinearity was not a problem in this study [77].

\subsection{Structural Paths and Hypotheses Tests}

Following validation of the measurement model, we used structural equation analysis to assess the relationships among the latent variables, applying AMOS 21.0. The results are presented in Table 4. The resulting indices indicated an appropriate model fit as well $\left(\chi^{2} / \mathrm{df}=2.765, \mathrm{CFI}=0.942\right.$, TLI $=0.933$, RMSEA $=0.066$, SRMR $=0.046$ ), based on the cutoff criteria in the literature [78].

Table 4 shows the standardized path coefficient and path significance for each path. Green value ( $\beta=0.285, t=3.223$ ) had a positive and significant effect on product attitude, as we hypothesized. Moreover, emotional value ( $\beta=0.573, t=4.027)$ and aesthetic value $(\beta=0.535, t=2.079)$ significantly affected product attitude. Supporting $\mathrm{H} 1, \mathrm{H} 3$, and $\mathrm{H} 4$, the green value, emotional value, and aesthetic value of upcycled products increased consumer upcycled product attitudes. However, the effects of functional value $(\beta=-0.264, t=-1.719)$, social value $(\beta=-0.009, t=-0.229)$, and self-expression value ( $\beta=-0.103, t=-0.697)$ were not significant: Thus, H2, H5, and H6 were not supported. In addition, product attitude was significantly associated with purchase intention $(\beta=0.974, t=20.970)$. Therefore, H7 was supported.

Table 4. Results of hypothesis testing.

\begin{tabular}{ccccccc}
\hline $\mathbf{H}$ & Path & $\boldsymbol{\beta}$ & S.E. & C.R. & Result & $\boldsymbol{R}^{\mathbf{2}}$ \\
\hline H1 & GV $\rightarrow$ PA & $0.285^{*}$ & 0.089 & 3.223 & Accepted & \\
H2 & FV $\rightarrow$ PA & -0.264 & 0.154 & -1.719 & Rejected & \\
H3 & EV $\rightarrow$ PA & $0.573^{* *}$ & 0.142 & 4.027 & Accepted & \\
H4 & AV $\rightarrow$ PA & $0.535^{* *}$ & 0.257 & 2.079 & Accepted & \\
H5 & SV $\rightarrow$ PA & -0.009 & 0.038 & -0.229 & Rejected & \\
H6 & SEV $\rightarrow$ PA & -0.103 & 0.149 & -0.697 & Rejected & 0.66 \\
H7 & PA $\rightarrow$ PI & 0.962 & 0.46 & 20.970 & Accepted & 0.74 \\
\hline
\end{tabular}

Notes: GV: Green value; FV: Functional value; EV: Emotional value; AV: Aesthetic value; SEV: Self-expression value; PA: Product attitude; PI: Purchase intention; $\chi^{2}=906.955(p=0.000, \mathrm{df}=328) ; \mathrm{CFI}=0.942 ; \mathrm{TLI}=0.933$; RMSEA $=0.066$; SRMR $=0.046 ;{ }^{* *}: p<0.01 ; *: p<0.05$.

Next, we tested for mediation effects of product attitude in the relationship between each product value and purchase intention using the bootstrap sampling method (bootstrap sample size $=5000$ ), as recommended by MacKinnon, Lockwood, and Williams [70], to generate the asymmetric confidence intervals (CIs) for indirect relationships. Table 5 shows the results of the mediating effects. The attitude toward upcycled products mediated the relationship between green value and purchase intention, as the $\mathrm{CI}(0.61,0.77)$ did not include zero. In addition, product attitude mediated the relationship between emotional value and purchase intention (CI of approximately $(0.58,0.85)$ ). Last, the $95 \% \mathrm{CI}$ of the mediating effect of product attitude on the relationship between aesthetic value and purchase intention did not include zero $(0.58,0.87)$. Therefore, $\mathrm{H} 8$ was partially supported. 
Table 5. Results of the bootstrapping method for mediation.

\begin{tabular}{lccccccccc}
\hline IV & $\mathbf{M}$ & DV & $\begin{array}{c}\text { Effect of IV } \\
\text { on M (a) }\end{array}$ & $\begin{array}{c}\text { Effect of M } \\
\text { on DV (b) }\end{array}$ & $\begin{array}{c}\text { Direct } \\
\text { Effect }\left(\mathbf{c}^{\prime}\right)\end{array}$ & $\begin{array}{c}\text { Indirect } \\
\text { Effect (a*b) }\end{array}$ & $\begin{array}{c}\text { Total } \\
\text { Effect (c) }\end{array}$ & 95\% CI & Result \\
\hline GV & PA & PI & $0.743^{* *}$ & $0.963^{* *}$ & -0.013 & $0.715^{* *}$ & $0.703^{* *}$ & $\begin{array}{c}(0.608 \\
0.772)\end{array}$ & Full \\
EV & PA & PI & $0.847^{* *}$ & $0.815^{* *}$ & $0.165^{*}$ & $0.702^{* *}$ & $0.867^{* *}$ & $\begin{array}{c}(0.581 \\
0.846)\end{array}$ & Partial \\
AV & PA & PI & $0.841^{* *}$ & $0.843^{* *}$ & $0.131^{*}$ & $0.708^{* *}$ & $0.839 * *$ & $(0.580$ & Partial \\
\hline
\end{tabular}

Notes: GV: Green value; FV: Functional value; EV: Emotional value; AV: Aesthetic value; SEV: Self-expression value; PA: Product attitude; PI: Purchase intention; CI: Confidence interval; ${ }^{*}$ shows significance at the 0.05 level; ** shows significance at the 0.01 level.

\subsection{Moderating Effects of Purchase Experience}

We hypothesized the moderating effect of the consumer's purchase experience in the relationship between each product value and product attitude. Therefore, we performed multiple group analyses to verify whether there were significant differences between purchasers and non-purchasers in the structural paths of the final model. Among the 401 respondents considered in the analysis, there were 211 purchasers and 190 non-purchasers. We estimated the significance of the differences between the two groups by comparing the $\chi^{2}$ statistics of the cross-group equality of the constrained and unconstrained models $[79,80]$. The $\chi^{2}$ difference test was barely significant except in constrained models 1 and 2 (Table 6). There was a moderating effect of the purchase experience in the relationship between green value and purchase attitude (variation of $\chi^{2}=8.987>\chi^{2} \cdot{ }_{05}(1)=3.84$, $\mathrm{df}=1$ ). When comparing the moderating effect between a purchaser and non-purchaser, the coefficient of the purchase attitude for the purchaser was .210, in comparison to .045 for the non-purchaser, indicating that the influence of green value on purchase intention was stronger among the purchasers (see Figure 2). Further, the $\chi^{2}$ difference test was significant (variation of $\chi^{2}=7.516>\chi^{2} \cdot 05(1)=3.84$, $\mathrm{df}=1$ ), showing that the unconstrained model performed substantially better than the constrained model 2. In other words, there was a moderating effect of the purchase experience in the relationship between functional value and product attitude. The results reveal that functional value had a significant positive effect on attitude only for purchasers $(\beta=0.178)$, while it was not significant for non-purchasers $(\beta=-0.070)$ (see Figure 3). Thus, H9 was partially supported.

Table 6. Moderating effects of purchase experience.

\begin{tabular}{|c|c|c|c|c|c|c|}
\hline Model & $x^{2}$ & df & CFI & RMSEA & $\triangle \chi^{2}$ & $p$-Value \\
\hline Free model & 44.099 & 12 & 0.989 & 0.079 & & \\
\hline $\begin{array}{c}\text { Constrained model } 1 \\
(\mathrm{GV} \rightarrow \mathrm{PA})\end{array}$ & 53.086 & 13 & 0.982 & 0.086 & 8.99 & $<0.001$ \\
\hline $\begin{array}{c}\text { Constrained model } 2 \\
(\mathrm{FV} \rightarrow \mathrm{PA})\end{array}$ & 51.615 & 13 & 0.983 & 0.085 & 7.52 & $<0.001$ \\
\hline $\begin{array}{c}\text { Constrained model } 3 \\
(\mathrm{EV} \rightarrow \mathrm{PA})\end{array}$ & 45.628 & 13 & 0.986 & 0.078 & & \\
\hline $\begin{array}{l}\text { Constrained model } 4 \\
(\mathrm{AV} \rightarrow \mathrm{PA})\end{array}$ & 44.146 & 13 & 0.987 & 0.077 & & \\
\hline $\begin{array}{c}\text { Constrained model } 5 \\
(\mathrm{SV} \rightarrow \mathrm{PA})\end{array}$ & 44.100 & 13 & 0.987 & 0.077 & & \\
\hline $\begin{array}{c}\text { Constrained model } 6 \\
(\mathrm{SEV} \rightarrow \mathrm{PA})\end{array}$ & 45.986 & 13 & 0.986 & 0.076 & & \\
\hline
\end{tabular}

Note: GV: Green value; FV: Functional value; EV: Emotional value; AV: Aesthetic value; SEV: Self-expression value; PA: Product attitude; PI: Purchase intention. 


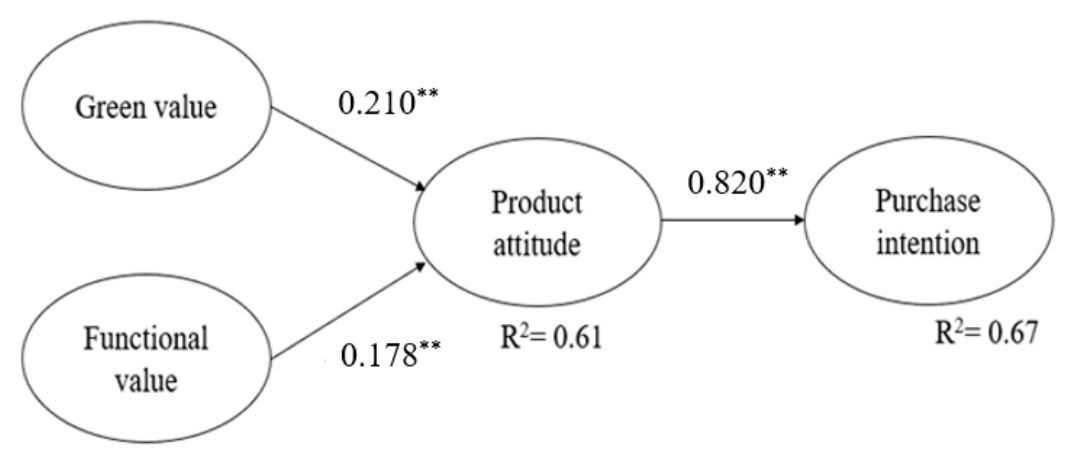

Figure 2. Coefficient in the path analysis (for purchasers). All path coefficients were standardized. $R^{2}$ refers to squared multiple correlation. Model fit indices: $\chi^{2}=34.820(p=0.000, \mathrm{df}=10), \mathrm{CFI}=0.989$; $\mathrm{TLI}=0.952 ; \mathrm{RMSEA}=0.066 ; \mathrm{SRMR}=0.046 ;{ }^{* *}: p<0.01, *: p<0.05$.

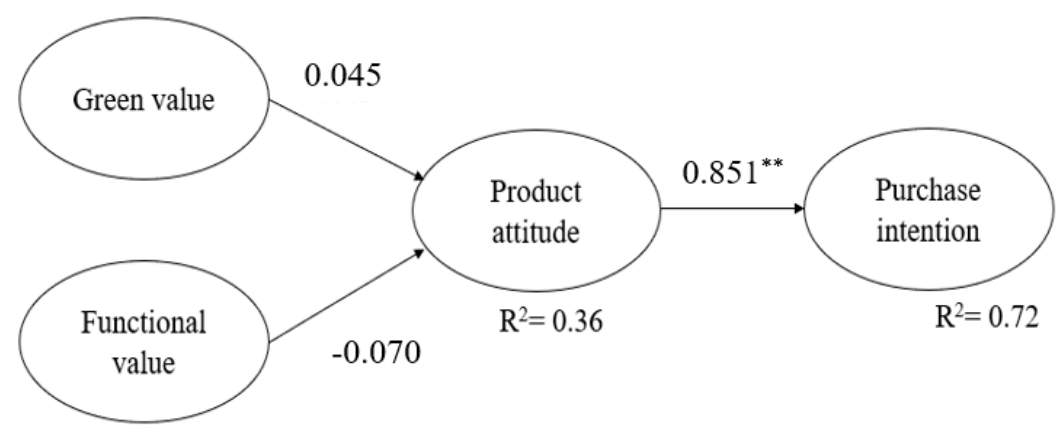

Figure 3. Coefficient in the path analysis (for non-purchasers). All path coefficients were standardized. $R^{2}$ refers to squared multiple correlation. Model fit indices: $\chi^{2}=34.820(p=0.000, \mathrm{df}=10), \mathrm{CFI}=0.989$; $\mathrm{TLI}=0.952 ; \mathrm{RMSEA}=0.066 ; \mathrm{SRMR}=0.046 ;{ }^{* *}: p<0.01, *: p<0.05$.

\section{Discussion}

The aim of our study was to investigate consumer purchase intention for upcycled products, focusing on consumption values. We also examined whether the perceived value and product attitude positively influenced purchasing behavior. Further, we tested the differences in the value perceptions of upcycled products between purchasers and non-purchasers. The results of the study point to several key findings.

First, the results revealed that green, emotional, and aesthetic values had a significant positive effect on upcycled product attitude among the six values used to capture the total perceived utility of an upcycled product (i.e., green, functional, emotional, aesthetic, social, and self-expression). Interestingly, in contrast to Wei and Jung [11], who analyzed a Chinese sample, here we were able to demonstrate the role of green value in the context of upcycled products. This contrast may have been a result of the samples used in each study. Our sample comprised individuals from the United States and, in fact, about $75 \%$ of all U.S. citizens think of themselves as "environmentalists" [81]. This study also found that respondents perceived aesthetic and emotional benefits in upcycled products. Product attributes, such as unique material and certain design, can attract consumers by fulfilling their aesthetic senses. The stories behind a product's rebirthing process may stimulate consumer interests and evoke positive emotions. The importance of aesthetic and emotional benefits is clearly contrasted by the benefits gained by using recycled products, which mainly concerns environmental values [5]. However, the effects of functional, social, and self-expression values on upcycled product attitude were not supported. This may have been because some people believe that the functionality of upcycled products remade out of discarded materials is not good enough. According to Luchs et al. [82], particularly in the case of sustainable products, the presence of a positive ethical attribute would result in the expectation of decreased performance in other attributes, and thus a consumer's product preference would decrease. Thus, our result implies that consumers still do not fully trust 
the product performance of upcycled products, although they are remade with better quality through craftsmanship and design. Furthermore, our results showed that upcycled products are not associated with symbolic benefits such as social values or self-expressiveness, and this finding is consistent with Park and Lin's study [13]. When we compared perceived product values by purchase experience, it was found that only the purchaser group perceived self-expressive value and formed a positive attitude toward upcycled products. Likewise, in Park and Lin's study [13], the actual purchasing experience increased perception of the self-expression value of upcycled products. These findings suggest that a consumer's purchase experience should be considered in examining product value, especially for ethical products such as upcycled products.

Second, this study found that environmental and functional values among six value dimensions toward the upcycled products were significantly different depending on purchase experience. Consumers who had purchase experience perceived the functional value of the upcycled product, which, in turn, affected the consumer's product attitude positively, whereas the influence of functional value was insignificant among non-purchasers. This study found a link between product knowledge and product evaluation. Although it is generally assumed that upcycled products have a functional risk, consumers who have purchased an upcycled product have more knowledge of the product stored in their memory than a non-purchaser, and thus they can evaluate the price and quality of the product more positively, which is consistent with the findings of prior studies $[14,83]$. This implies that it is critical to make consumers use the upcycled product first to inform them about the functional value of the product. Similarly, in contrast to non-purchasers, purchasers perceived the product's green value and formed a positive attitude toward the upcycled product. These results can be interpreted in that compared to non-purchasers, actual purchasers of upcycled products placed a higher emphasis on the environmental aspects of the upcycled product. This finding is in line with the findings of Ahn and Jung [54]. Overall, the results reveal that the environmental and functional value of upcycled products affected consumers' product attitudes for repetitive purchasers, and that consumers' actual purchasing experience played an important role in those relationships.

Third, we applied a causal model of consumption value and product attitudes to determine factors that affect the purchasing intention of the upcycled product, and the results revealed that attitudes toward upcycled products played an important mediating role. More interestingly, the aesthetic and emotional value of the upcycled product had a direct impact on purchase intention, while the environmental value was found to affect purchase intention through an attitude toward the upcycled product. This means that, as with Chen and Chang [17], green values affected purchase intention through green trust. Important parameters such as product attitude and product trust should be included in explaining the effect of value on purchase behavior. In contrast, Wei and Jung [11] showed that there was no influence on the green value of a sustainable product on behavioral intention, possibly suggesting that there could be other important parameters.

\section{Conclusions}

Our study contributes to the literature stream on upcycling by enhancing our understanding of the effects of consumer perceived values on such products. Existing studies on upcycling have mainly focused on the concept of upcycling, the manufacturing process of upcycling, or product design issues adopting the upcycled technology. Research on consumer perceptions or behaviors toward commercial upcycled products has been limited. In this study, we identified the main consumption value dimensions of upcycled products and examined the relationship between product attitude and purchase intention using U.S. consumer samples who were familiar with upcycled products. We proved that green value, as an environmental aspect, was a significant predictor when forming a positive attitude and making a purchase decision. Moreover, in particular, emotional and aesthetic value, as hedonic values, had a strong influence as well. These results may be interpreted in that upcycled products can attract consumers to better meet aesthetic and emotional, as well as green, value of upcycled products by emphasizing unique design approaches, maintaining environmental value 
compared to recycled products that emphasize only environmental values with low-growth orientation and lack of aesthetic pursuit [31]. In other words, we propose the necessity of a comparative study of recycled products and upcycled products by demonstrating that recycled products and upcycled products have different consumption values even if they are the same eco-friendly products. From a managerial point of view, organizations such as businesses, industry associations, and governments associated with the upcycling business can use this information to apply to promotional and relevant marketing communication strategies. For example, they can promote awareness among consumers of the importance of their contribution to environmental and resource conservation as a member of society by purchasing upcycled products. Moreover, practitioners can design strategies that maximize the emotional and aesthetic values of the upcycled product through varied and engaging content, such as storytelling, based on the product's background, offering experiential marketing where consumers can create such products themselves through upcycling, as well as collaboration with local designers.

Further, this research included purchasing experience to compare the differences between purchasers and non-purchasers. In the consumer's consumption value of upcycled products, in particular, green values, functional values, and the actual purchase experience of consumers played an important role in shaping a positive attitude toward upcycled products. Consumers with actual purchase experience should be exposed to information that emphasizes environmental value by exposing promotional messages demonstrating the manufacturing process of upcycling or by marking green labels salient to encourage repurchase behavior. In addition, distribution and promotional strategies should be devised to make purchasers recognize the functional value of the upcycled product by actively exposing clues that prove the quality of the upcycled product and making it easier to purchase the product with a variety of product assortment.

\section{Limitations and Future Research}

However, despite our several contributions, this study had some limitations that point to areas for future research scope. This study verified that consumers purchased upcycled products for practical or internal purposes, looking at various product categories such as furniture, office supplies, ornaments, and fashion. According to a prior study [84], consumer perceived value varies depending on product type, and thus, future studies are needed to deepen understanding of the other values related to the upcycled product. Specifically, it would be meaningful to examine the role of economic value in determining attitude and purchase intention toward upcycled products. Second, the role of social value was not supported in this study. This implies that an upcycled product, made of abandoned materials, is not recognized as a trendy image or worth showing off. Consumers may have concerns about how these will be accepted. Therefore, a further study is needed to explore how this risk negatively affects the purchasing intent of upcycled products. Third, we applied an attitude-toward-object model, which is the basic model of Fishbein to explain our research model. Considering that the most appropriate theory to explain action from attitude is the theory of reasoned action (TRA) [85], the applied theory of our research was limited in predicting consumers' actual behavior. Therefore, further research on upcycled products based on the TRA, which includes subjective norms and attitudes, is needed, thereby addressing the ethical purchasing gap. Fourth, the measurement scales of purchase intention in this study could have been a limitation. The current study used general versions of the scale of purchase intention with no time inference. If there is no time reference point, the intention-behavior gap may increase [38], so a time reference point (e.g., "I might purchase upcycled products in the next month") in the statement is needed. Therefore, in order to accurately predict behaviors of consumers, future research is needed to measure purchase intention with a time reference point. Next, the current study focused on a consumer's purchase experience as a moderating variable in the relationship between value and attitude. Although other consumer characteristics such as education level and income can be regarded as important variables, those variables were not included in this study. For example, many prior studies have found that level of education is an important demographic variable that has been linked to environmental attitudes and behavior [86]. Thus, it would be interesting 
to examine how upcycling value perceptions and attitudes differ by the level of education. Finally, future studies should replicate this research using samples from the U.S. to test its generalizability. By doing this, we believe that we can obtain more confirmed findings and provide evidence for external validity. In addition, as environmental awareness appears to be influenced by culture [87], it would be interesting to explore and examine cross-cultural comparisons between individualism and collectivism cultures.

Author Contributions: This paper was conceived and designed by S.Y. and J.L.; S.Y collected and analyzed data under the supervision of J.L; all authors wrote and reviewed the paper.

Funding: This research received no external funding.

Conflicts of Interest: The authors declare no conflict of interest.

\section{Appendix A}

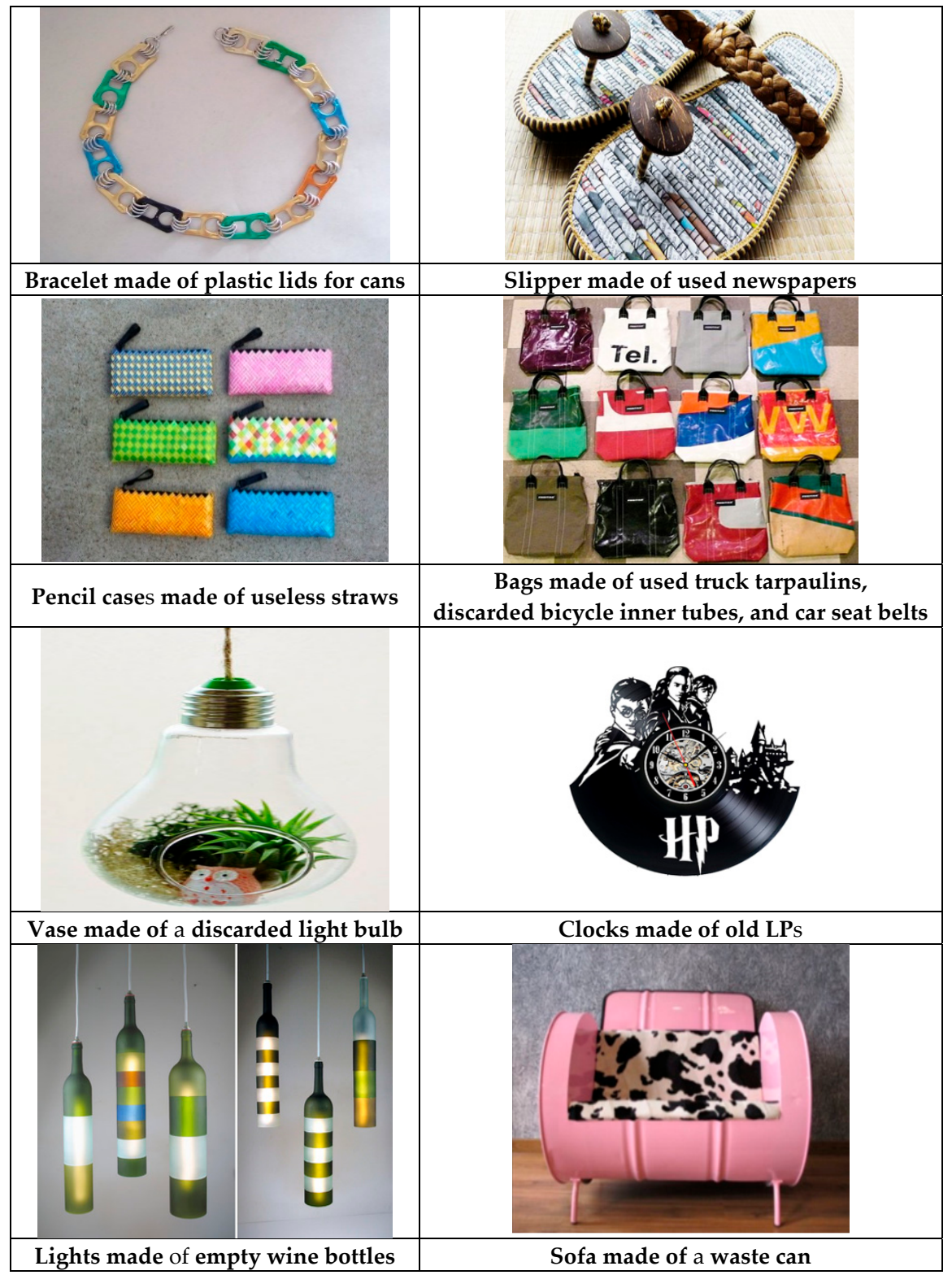

Figure A1. Exemplary images of upcycled products. 


\section{References}

1. Osmani, M.; Glass, J.; Price, A.D. Architects' perspectives on construction waste reduction by design. Waste Manag. 2008, 28, 1147-1158. [CrossRef] [PubMed]

2. Wang, J. Upcycling Becomes a Treasure Trove for Green Business Ideas. 2011. Available online: https: / / www.entrepreneur.com/article/219310 (accessed on 16 February 2019).

3. Bridgens, B.; Powell, M.; Farmer, G.; Walsh, C.; Reed, E.; Royapoor, M.; Gosling, P.; Hall, J.; Heidrich, O. Creative upcycling: Reconnecting people, materials and place through making. J. Clean. Prod. 2018, 189, 145-154. [CrossRef]

4. Teli, M.; Valia, S.P.; Maurya, S.; Shitole, P. Sustainability Based Upcycling and Value Addition of Textile Apparels. 2014. Available online: http:/ / globalilluminators.org/wp-content/uploads/2014/09/MISG-14-144.pdf (accessed on 16 February 2019).

5. Ali, N.S.; Khairuddin, N.F.; Zainal Abidin, S. Upcycling: Re-Use and Recreate Functional Interior Space Using Waste Materials. In Proceedings of the 15th International Conference on Engineering and Product Design Education, Dublin, Ireland, 5-6 September 2013; pp. 798-803.

6. McDonough, W.; Braungart, M. Design for the triple top line: New tools for sustainable commerce. Corp. Environ. Strategy 2002, 9, 251-258. [CrossRef]

7. XU, J.; Gu, P. Five principles of waste product redesign under the upcycling concept. In Proceedings of the International Forum on Energy, Environment Science and Materials (IFEESM 2015), Shenzhen, China, 25-26 September 2015.

8. Sung, K. Sustainable Production and Consumption by Upcycling: Understanding and Scaling-Up Niche Environmentally Significant Behaviour. Ph.D. Thesis, Nottingham Trent University, Nottingham, UK, 2017.

9. Park, H.H. The influence of lohas consumption tendency and perceived consumer effectiveness on trust and purchase intention regarding upcycling fashion goods. Int. J. Hum. Ecol. 2015, 16, 37-47. [CrossRef]

10. Wilson, M. When creative consumers go green: Understanding consumer upcycling. J. Prod. Brand Manag. 2016, 25, 394-399. [CrossRef]

11. Wei, X.; Jung, S. Understanding chinese consumers' intention to purchase sustainable fashion products: The moderating role of face-saving orientation. Sustainability 2017, 9, 1570.

12. Fishbein, M.; Ajzen, I. Attitudes towards objects as predictors of single and multiple behavioral criteria. Psychol. Rev. 1974, 81, 59-74. [CrossRef]

13. Park, H.J.; Lin, L.M. Exploring attitude-behavior gap in sustainable consumption: Comparison of recycled and upcycled fashion products. J. Bus. Res. 2018. [CrossRef]

14. Salazar-Ordóñez, M.; Rodríguez-Entrena, M.; Cabrera, E.R.; Henseler, J. Understanding product differentiation failures: The role of product knowledge and brand credence in olive oil markets. Food Qual. Prefer. 2018, 68, 146-155. [CrossRef]

15. Rao, A.R.; Monroe, K.B. The moderating effect of prior knowledge on cue utilization in product evaluations. J. Consum. Res. 1988, 15, 253-264. [CrossRef]

16. Sheth, J.N.; Newman, B.I.; Gross, B.L. Why we buy what we buy: A theory of consumption values. J. Bus. Res. 1991, 22, 159-170. [CrossRef]

17. Chen, Y.-S.; Chang, C.-H. Enhance green purchase intentions: The roles of green perceived value, green perceived risk, and green trust. Manag. Decis. 2012, 50, 502-520. [CrossRef]

18. Slotegraaf, R.J. Keep the door open: Innovating toward a more sustainable future. J. Prod. Innov. Manag. 2012, 29, 349-351. [CrossRef]

19. Steinhilper, R.; Hieber, M. In Remanufacturing-the key solution for transforming" downcycling" into" upcycling" of electronics. 2001. In Proceedings of the 2001 IEEE International Symposium on Electronics and the Environment, Denver, CO, USA, 7-9 May 2001.

20. Braungart, M.; McDonough, W.; Bollinger, A. Cradle-to-cradle design: Creating healthy emissions-A strategy for eco-effective product and system design. J. Clean. Prod. 2007, 15, 1337-1348. [CrossRef]

21. Sung, K. A review on upcycling: Current body of literature, knowledge gaps and a way forward. In Proceedings of the ICECESS 2015: 17th International Conference on Environmental, Cultural, Economic and Social Sustainability, Venice, Italy, 13-14 April 2015.

22. Goldsmith, B. Trash or treasure? Upcycling becomes growing green trend. Retrieved 2009, 9, 2013. 
23. Paraskevas, D.; Kellens, K.; Dewulf, W.; Duflou, J.R. Sustainable metal management and recycling loops: Life cycle assessment for aluminium recycling strategies. In Re-Engineering Manufacturing for Sustainability; Springer: Berlin/Heidelberg, Germany, 2013; pp. 403-408.

24. Zeithaml, V.A. Consumer perceptions of price, quality, and value: A means-end model and synthesis of evidence. J. Mark. 1988, 52, 2-22. [CrossRef]

25. Sweeney, J.C.; Soutar, G.N. Consumer perceived value: The development of a multiple item scale. J. Retail. 2001, 77, 203-220. [CrossRef]

26. Holbrook, M.B. Customer value and autoethnography: Subjective personal introspection and the meanings of a photograph collection. J. Bus. Res. 2005, 58, 45-61. [CrossRef]

27. Keller, K.L. Conceptualizing, measuring, and managing customer-based brand equity. J. Mark. 1993, 57, 1-22. [CrossRef]

28. Kumar, M.; Noble, C.H. Beyond form and function: Why do consumers value product design? J. Bus. Res. 2016, 69, 613-620. [CrossRef]

29. Bakker, C.; Wang, F.; Huisman, J.; den Hollander, M. Products that go round: Exploring product life extension through design. J. Clean. Prod. 2014, 69, 10-16. [CrossRef]

30. Sung, K.; Cooper, T. Sarah turner-eco-artist and designer through craft-based upcycling. Craft Res. 2015, 6, 113-122. [CrossRef]

31. Kwan, J.-S. Based on the perspective of sustainability, the characteristics of upcycle fashion design. Fash. Text. Res. J. 2012, 14, 13-23. [CrossRef]

32. McColl, J.; Canning, C.; McBride, L.; Nobbs, K.; Shearer, L. It's vintage darling! An exploration of vintage fashion retailing. J. Text. Inst. 2013, 104, 140-150. [CrossRef]

33. Belk, R.W. Possessions and the extended self. J. Consum. Res. 1988, 15, 139-168. [CrossRef]

34. Sirgy, M.J.; Grewal, D.; Mangleburg, T.F.; Park, J.-O.; Chon, K.-S.; Claiborne, C.B.; Johar, J.; Berkman, H. Assessing the predictive validity of two methods of measuring self-image congruence. J. Acad. Mark. Sci. 1997, 25, 229-241. [CrossRef]

35. Sung, K.; Cooper, T.; Kettley, S. An exploratory study on the consequences of individual upcycling: Is it worth making people feel attached to their upcycled products? In Proceedings of the CADBE Doctoral Conference 2015, Nottingham, UK, 8-9 June 2015.

36. Mugge, R.; Schoormans, J.P.; Schifferstein, H.N. Product attachment: Design strategies to stimulate the emotional bonding to products. In Product Experience; Elsevier: Amsterdam, The Netherlands, 2008.

37. Fishbein, M.; Ajzen, I. Belief, Attitude, Intention and Behavior: An Introduction to Theory and Research; Addison-Wesley: Reading, MA, USA, 1975.

38. Kraus, S.J. Attitudes and the prediction of behavior: A meta-analysis of the empirical literature. Personal. Soc. Psychol. Bull. 1995, 21, 58-75. [CrossRef]

39. Kong, H.M.; Ko, E.; Chae, H.; Mattila, P. Understanding fashion consumers' attitude and behavioral intention toward sustainable fashion products: Focus on sustainable knowledge sources and knowledge types. J. Glob. Fash. Mark. 2016, 7, 103-119. [CrossRef]

40. Chen, Y.-S.; Hung, S.-T.; Wang, T.-Y.; Huang, A.-F.; Liao, Y.-W. The influence of excessive product packaging on green brand attachment: The mediation roles of green brand attitude and green brand image. Sustainability 2017, 9, 654. [CrossRef]

41. Fazio, R.H. Multiple processes by which attitudes guide behavior: The mode model as an integrative framework. In Advances in Experimental Social Psychology; Elsevier: Amsterdam, The Netherlands, 1990.

42. Engel, J.; Blackwell, R.; Miniard, P. Consumer Behavior; Dryden: New York, NY, USA, 1978.

43. Homer, P.M.; Kahle, L.R. A structural equation test of the value-attitude-behavior hierarchy. J. Personal. Soc. Psychol. 1988, 54, 638-646. [CrossRef]

44. Norman, P.; Smith, L. The theory of planned behaviour and exercise: An investigation into the role of prior behaviour, behavioural intentions and attitude variability. Eur. J. Soc. Psychol. 1995, 25, 403-415. [CrossRef]

45. Carrus, G.; Passafaro, P.; Bonnes, M. Emotions, habits and rational choices in ecological behaviours: The case of recycling and use of public transportation. J. Environ. Psychol. 2008, 28, 51-62. [CrossRef]

46. Van der Linden, S. Charitable intent: A moral or social construct? A revised theory of planned behavior model. Curr. Psychol. 2011, 30, 355-374. [CrossRef]

47. Moore, G. The fair trade movement: Parameters, issues and future research. J. Bus. Ethics 2004, 53, 73-86. [CrossRef] 
48. Pickett-Baker, J.; Ozaki, R. Pro-environmental products: Marketing influence on consumer purchase decision. J. Consum. Mark. 2008, 25, 281-293. [CrossRef]

49. Alba, J.W.; Hutchinson, J.W. Dimensions of consumer expertise. J. Consum. Res. 1987, 13, 411-454. [CrossRef]

50. Bettman, J.R.; Sujan, M. Effects of framing on evaluation of comparable and noncomparable alternatives by expert and novice consumers. J. Consum. Res. 1987, 14, 141-154. [CrossRef]

51. Park, C.W.; Lessig, V.P. Familiarity and its impact on consumer decision biases and heuristics. J. Consum. Res. 1981, 8, 223-230. [CrossRef]

52. Park, C.W.; Mothersbaugh, D.L.; Feick, L. Consumer knowledge assessment. J. Consum. Res. 1994, $21,71-82$. [CrossRef]

53. Zanna, M.P.; Fazio, R. Direct experience and attitude-behavior consistency. Adv. Exp. Soc. Psychol. 1981, 14, 162-202.

54. Ahn, C.-H.; Jung, S. Characteristics of purchasers and non-purchasers of environmental products. Home Manag. Assoc. Korea 2004, 22, 55-64. [CrossRef]

55. Sung, K.; Cooper, T.; Kettley, S. Individual Upcycling Practice: Exploring the Possible Determinants of Upcycling Based on a Literature Review. In Proceedings of the Sustainable Innovation Conference, Copenhagen, Denmark, 3-4 November 2014.

56. Snoj, B.; Pisnik Korda, A.; Mumel, D. The relationships among perceived quality, perceived risk and perceived product value. J. Prod. Brand Manag. 2004, 13, 156-167. [CrossRef]

57. Gentile, C.; Spiller, N.; Noci, G. How to sustain the customer experience:: An overview of experience components that co-create value with the customer. Eur. Manag. J. 2007, 25, 395-410. [CrossRef]

58. Clarkson, J.J.; Janiszewski, C.; Cinelli, M.D. The desire for consumption knowledge. J. Consum. Res. 2012, 39, 1313-1329. [CrossRef]

59. Leder, H.; Belke, B.; Oeberst, A.; Augustin, D. A model of aesthetic appreciation and aesthetic judgments. Br. J. Psychol. 2004, 95, 489-508. [CrossRef] [PubMed]

60. Jacobsen, T. Beauty and the brain: Culture, history and individual differences in aesthetic appreciation. J. Anat. 2010, 216, 184-191. [CrossRef] [PubMed]

61. Gardial, S.F.; Clemons, D.S.; Woodruff, R.B.; Schumann, D.W.; Burns, M.J. Comparing consumers' recall of prepurchase and postpurchase product evaluation experiences. J. Consum. Res. 1994, 20, 548-560. [CrossRef]

62. Jensen, H.R. Antecedents and consequences of consumer value assessments: Implications for marketing strategy and future research. J. Retail. Consum. Serv. 2001, 8, 299-310. [CrossRef]

63. Simintiras, A.; Diamantopoulos, A.; Ferriday, J. Pre-purchase satisfaction and first-time buyer behaviour: Some preliminary evidence. Eur. J. Mark. 1997, 31, 857-872. [CrossRef]

64. Boztepe, S. User value: Competing theories and models. Int. J. Des. 2007, 1, 55-63.

65. McCright, A.M.; Dentzman, K.; Charters, M.; Dietz, T. The influence of political ideology on trust in science. Environ. Res. Lett. 2013, 8, 044029. [CrossRef]

66. Jung Choo, H.; Moon, H.; Kim, H.; Yoon, N. Luxury customer value. J. Fash. Mark. Manag. 2012, 16, 81-101. [CrossRef]

67. Till, B.D.; Busler, M. The match-up hypothesis: Physical attractiveness, expertise, and the role of fit on brand attitude, purchase intent and brand beliefs. J. Advert. 2000, 29, 1-13. [CrossRef]

68. Lee, J.; Kim, J.; Yu, J. Effects of congruence of product, visual image, and consumer self-image on art infusion advertising. Soc. Behav. Personal. 2015, 43, 1725-1740. [CrossRef]

69. Byrne, B.M. Structural Equation Modeling with Amos: Basic Concepts, Applications, and Programming; Routledge: Abington, UK, 2016.

70. MacKinnon, D.P.; Lockwood, C.M.; Williams, J. Confidence limits for the indirect effect: Distribution of the product and resampling methods. Multivar. Behav. Res. 2004, 39, 99-128. [CrossRef] [PubMed]

71. Hu, L.T.; Bentler, P.M. Cutoff criteria for fit indexes in covariance structure analysis: Conventional criteria versus new alternatives. Struct. Equ. Model. Multidiscip. J. 1999, 6, 1-55. [CrossRef]

72. Bagozzi, R.P.; Yi, Y. On the evaluation of structural equation models. J. Acad. Mark. Sci. 1988, 16, 74-94. [CrossRef]

73. Hair, J.F.; Anderson, R.E.; Tatham, R.L.; Black, W.C. Multivariate Data Analysis, 3rd ed.; Prentice Hall: Upper Saddle River, NJ, USA, 1998.

74. Fornell, C.; Larcker, D.F. Structural equation models with unobservable variables and measurement error: Algebra and statistics. J. Mark. Res. 1981, 18, 382-388. [CrossRef] 
75. Podsakoff, P.M.; Organ, D.W. Self-reports in organizational research: Problems and prospects. J. Manag. 1986, 12, 531-544. [CrossRef]

76. Sania, U.; Kalpina, K.; Javed, H. Diversity, employee morale and customer satisfaction: The three musketeers. J. Econ. Bus. Manag. 2015, 3, 11-18. [CrossRef]

77. Graham, M.H. Confronting multicollinearity in ecological multiple regression. Ecology 2003, 84, $2809-2815$. [CrossRef]

78. Ahluwalia, R. How prevalent is the negativity effect in consumer environments? J. Consum. Res. 2002, 29, 270-279. [CrossRef]

79. Hwang, K.; Lee, J. Antecedents and consequences of ecotourism behavior: Independent and interdependent self-construals, ecological belief, willingness to pay for ecotourism services and satisfaction with life. Sustainability 2018, 10, 789. [CrossRef]

80. Guido, G.; Prete, M.I.; Peluso, A.M.; Maloumby-Baka, R.C.; Buffa, C. The role of ethics and product personality in the intention to purchase organic food products: A structural equation modeling approach. Int. Rev. Econ. 2010, 57, 79-102. [CrossRef]

81. Kempton, W.; Boster, J.S.; Hartley, J.A. Environmental Values in American Culture; MIT Press: Cambridge, MA, USA, 1995.

82. Luchs, M.G.; Naylor, R.W.; Irwin, J.R.; Raghunathan, R. The sustainability liability: Potential negative effects of ethicality on product preference. J. Mark. 2010, 74, 18-31. [CrossRef]

83. Kalogeras, N.; Valchovska, S.; Baourakis, G.; Kalaitzis, P. Dutch consumers' willingness to pay for organic olive oil. J. Int. Food Agribus. Mark. 2009, 21, 286-311. [CrossRef]

84. Ulaga, W. Capturing value creation in business relationships: A customer perspective. Ind. Mark. Manag. 2003, 32, 677-693. [CrossRef]

85. Ajzen, I.; Fishbein, M. Understanding Attitudes and Predicting Social Behaviour; Prentice-Hall: Englewood Cliffs, NJ, USA, 1980; ISBN 0139364439.

86. Straughan, R.D.; Roberts, J.A. Environmental segmentation alternatives: A look at green consumer behavior in the new millennium. J. Consum. Mark. 1999, 16, 558-575. [CrossRef]

87. Kim, Y.; Choi, S.M. Antecedents of green purchase behavior: An examination of collectivism, environmental concern, and pce. ACR N. Am. Adv. 2005, 32, 592-599.

(C) 2019 by the authors. Licensee MDPI, Basel, Switzerland. This article is an open access article distributed under the terms and conditions of the Creative Commons Attribution (CC BY) license (http:/ / creativecommons.org/licenses/by/4.0/). 